International Journal of Agriculture, Environment and Bioresearch

Vol. 5, No. 06; 2020

ISSN: $2456-8643$

\title{
ASSESSMENT OF TRANSFER OF AGRICULTURAL TECHNOLOGIES BY EXTENSION AGENTS TO CROP FARMERS IN OGUN STATE, NIGERIA
}

\author{
"OYETORO John Oyewole, ${ }^{* *}$ JOLAYEMI John Olalere and *Rahman, S. B \\ "Department of Agricultural Extension and Rural Development ,Ladoke Akintola University of Technology, \\ Ogbomoso, Nigeria \\ ** Department of Agricultural Science Education,College of Education, Oro, Kwara State, Nigeria.
}

https://doi.org/10.35410/IJAEB.2020.5595

\begin{abstract}
The study assessed Agricultural technologies transferred by Extension Agents to crop farmers in Ogun State, Nigeria. Data was collected from sixty one (61) respondents with the aid of questionnaire. Findings revealed that mean age of Extension Agents in the study area was 40.3 years. The mean years spent in formal school was 16.30 years and the mean annual income was N479,080.00. The key agricultural technologies transferred to crop farmers were hybrid maize (WMS $=1.95$ ) and technology on plant population (WMS=1.93). Face to face $(92.4 \%)$ and Demonstrations $(96.7 \%)$ were the two major communication channels employed by respondents in transferring Agricultural technologies to crop farmers. Significant relationship existed between selected socio economic characteristics such as age $(\mathrm{r}=0.277, \mathrm{p}=0.030)$, years spent in school $(r=0.713, p=0.000)$ and the level of transfer of Agricultural technologies by Extension agents. The study recommended that more extension agents should be recruited into extension services to expand their coverage in the state.
\end{abstract}

Keywords: Technology, Agricultural technology, Extension, Technology transfer.

\section{INTRODUCTION}

Agricultural extension is essentially a service as well as learning process for farmers.It is the basis of the transfer of agricultural technologies to farmers' populace and to persuade them to utilize those agricultural techniques. The traditional view of agricultural extension in developing countries was very much focused on increasing production, improving yields, training farmers, and transferring technology (Davis, 2008). Technological change and utilization of innovation production techniques are important steps in the development process of every agrarian economy. This is especially true for agricultural development in Sub-Saharan Africa, where crop output has largely been stagnant for many years due to a multiplicity of factors including poor adoption and inadequate use of improved production methods (Azumah et al, 2018).

Agricultural technology transfer methods connote techniques used by an extension system as it functions such as face to face, demonstration, mass media and so on. A combination of methods is considered suitable and appropriate for a given agricultural technology. Mgendi, Shiping and Xiang (2019) stated that Agricultural technology transfer plays a chief role in transforming agricultural productivity in rural areas especially in the current setting where food demand 
Vol. 5, No. 06; 2020

ISSN: $2456-8643$

surpasses the production capacity. Technology transfer facilitates the movement of soft and hard skills essential for improving farm production.

The issue of climate change which affects food production necessitates invention and transfer of suitable agricultural technologies to crop farmers. The challenges to the transfer of agricultural technologies in Nigeria can be grouped into four broad categories according to Ohikere and Arudi (2011) which are:

- The problem with the technology itself

- The problem with the technological transfer system

- Socio-economic attributes of farmers

- Local peculiarities and differences.

Technology transfer and utilization is one of the reasons yield gap exists. Farmers do not have sufficient economic incentives to adopt yield enhancing seeds or cropping techniques. This may be explained by numerous factors, including lack of access to information, extension services and technical skills. Poor infrastructure, weak institutions and unfavourable farm policies can also create huge obstacles to the adoption of improved technologies at farm-level. Other factors can be that available technologies have not been adapted to local conditions (Food and Agricultural Organization, 2009). However, extension agents are poorly motivated in terms of remuneration and provision of transport facilities to visit the farmers. Specifically, the study:

- Ascertained selected socio-economic characteristics of crop farmers.

- Determined the agricultural technologies transferred to the crop farmers.

- Determine the communication channels used to transfer agricultural technologies.

\section{METHODOLOGY}

The study was carried out in Ogun State, Nigeria. It borders Lagos state to the south, Oyo and Osun State to the North, Ondo state to the east and Republic of Benin to the west. The state is within the tropical rain forest with abundance of resources, which enables residents to produce Agricultural Cash crops likeOil palm and coconut, arable crops like yam, cassava, and maize, are widely cultivated there too.Ogun state is divided into four (4) Agricultural zones by Ogun State Agricultural Development Project (OGADEP) namely Abeokuata Zone, Ikenne Zone, Ilaro Zone and Ijebu Ode Zone.

Based on the population of Extension Agents in all the four Agricultural zones in the state, all Extension Agents (61) in the four zones, were used as respondents.Data was collected from the respondents through the administration of questionnaire.Two types of variables were considered in the study. They are dependent and independent variables. The dependent variable is level of transfer of Agricultural technologies to crop farmers by the respondents, which was measured on a 3 rating scale of Always transferred (2), Occasional transferred (1) and not transferred (1). The descriptive tools include mean, frequency counts, percentages. While Pearson Product Moment Correlation (PPMC) analysis was used to test for the hypothesis.

\section{DISCUSSION OF RESULTS}




\section{Socio economic characteristics of respondents}

Table 1 revealed the distribution of respondents according to their socio economic characteristics. It can be observed that mean age of Extension Agents in the study area was 40.3 years. This means respondents were in their active ages which could assist them to be productive in the transfer of latest agricultural technologies to farmers. The mean years spent in formal

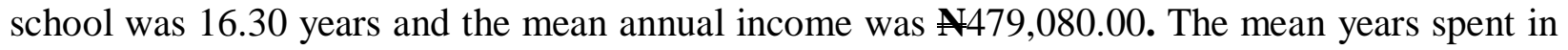
formal school was 16.30 years and this implies that respondents in the study area were highly educated. The mean household size was 4 persons and it implies that respondents in the study area had a very small household size.

Table 1: Distribution of respondents according to their socio economic characteristics

$$
n=61
$$

\begin{tabular}{|c|c|c|c|}
\hline Socio economic characteristics & Frequency & Percentage & Mean \\
\hline \multicolumn{4}{|l|}{ Age (years) } \\
\hline$<30$ & 9 & 14.8 & \multirow{9}{*}{40.3} \\
\hline $31-40$ & 25 & 40.9 & \\
\hline 41 years and above & 27 & 44.3 & \\
\hline \multicolumn{3}{|l|}{ Sex } & \\
\hline Male & 39 & 63.9 & \\
\hline Female & 22 & 36.1 & \\
\hline \multicolumn{3}{|l|}{ Marital status } & \\
\hline Single & 6 & 9.8 & \\
\hline Married & 55 & 90.2 & \\
\hline \multicolumn{4}{|l|}{ Years spent in school } \\
\hline$<12$ & 3 & 4.9 & \multirow{3}{*}{16.3} \\
\hline $13-18$ & 50 & 82.0 & \\
\hline 19 and above & 8 & 13.1 & \\
\hline \multicolumn{4}{|l|}{ Household size (persons) } \\
\hline$<4$ & 34 & 41.7 & \multirow[t]{3}{*}{4} \\
\hline $5-8$ & 23 & 37.7 & \\
\hline 9 and above & 4 & 6.6 & \\
\hline \multicolumn{4}{|l|}{ Annual income } \\
\hline$<\mathrm{N} 500,000$ & 31 & 50.8 & $\mathrm{~N} 479,080$ \\
\hline N500,001 and above & 29 & 49.2 & \\
\hline
\end{tabular}

\section{Source: Field survey, 2019}

\section{Agricultural Technologies transferred by Extension Agents to crop farmers.}

Table 2 revealed the distribution of the respondents according to frequency of transfer of agricultural technologies to crop farmers in the study area and it indicated that the major agricultural technologies transferred to crop farmers was transfer of hybrid maize technology and was ranked first with a weighted mean score (WMS) of 1.95, followed by plant spacing 
information was ranked second with a weighted mean score (WMS) of 1.93, followed information on plant population was ranked third with a weighted mean score (WMS) of 1.87, followed by technology on improved grains varieties and technology on improved cassava stem was ranked fourth with a weighted mean score (WMS) of 1.85 respectively while technology transferred on plant extraction and water melon were ranked least with the weighted mean score (WMS) of 0.48 and 0.23 respectively. The result of the findings shows that technology transferred on hybrid maize, plant spacing, plant population and improved grains varieties were the major Agricultural technologies transferred by Extension agent to crop farmers in the study area.

Table 2: Distribution of respondents according to Agricultural technologies transferred to crop farmers

\begin{tabular}{|c|c|c|c|c|c|}
\hline \multirow[t]{2}{*}{ Agricultural Technologies } & \multicolumn{5}{|c|}{ Frequency of Transfer } \\
\hline & $\begin{array}{l}\text { Always } \\
\text { transferred }\end{array}$ & $\begin{array}{l}\text { Occasional } \\
\text { transferred }\end{array}$ & $\begin{array}{l}\text { Not } \\
\text { transferred }\end{array}$ & WMS & Rank \\
\hline \multicolumn{6}{|l|}{ Arable crops } \\
\hline Improved grains varieties & $52(85.2)$ & $9(14.8)$ & $0(0.00)$ & 1.85 & $4^{\text {th }}$ \\
\hline Spacing & $57(93.4)$ & $4(6.6)$ & $0(0.00)$ & 1.93 & $2^{\text {nd }}$ \\
\hline Plant population & $53(86.9)$ & $8(13.1)$ & $0(0.00)$ & 1.87 & $3^{\text {rd }}$ \\
\hline Weeding technique (chemical) & $40(65.6)$ & $13(21.3)$ & $8(13.1)$ & 1.52 & $10^{\text {th }}$ \\
\hline \multicolumn{6}{|l|}{ Fertilizer } \\
\hline Organic (quantity) & $11(18.0)$ & $18(29.5)$ & $32(52.5)$ & 0.66 & $14^{\text {th }}$ \\
\hline Organic (quality) & $5(8.2)$ & 21(34.4) & $35(57.4)$ & 0.51 & $16^{\text {th }}$ \\
\hline Inorganic (Adequacy) & $29(47.5)$ & $26(42.6)$ & $6(9.8)$ & 1.38 & $12^{\text {th }}$ \\
\hline Inorganic (availability) & $30(49.2)$ & $25(41.0)$ & $6(9.8)$ & 1.39 & $11^{\text {th }}$ \\
\hline \multicolumn{6}{|l|}{ Pesticides } \\
\hline Chemical & $51(83.6)$ & $10(16.4)$ & $0(0.00)$ & 1.84 & $6^{\text {th }}$ \\
\hline Plant extraction & $3(4.9)$ & $23(37.7)$ & $35(57.4)$ & 0.48 & $17^{\text {th }}$ \\
\hline \multicolumn{6}{|l|}{ Improved seed distribution } \\
\hline Hybrid maize & $58(95.1)$ & $3(4.9)$ & $0(0.00)$ & 1.95 & $1^{\text {st }}$ \\
\hline Cassava stem & $52(85.2)$ & $9(14.8)$ & $0(0.00)$ & 1.85 & $4^{\text {th }}$ \\
\hline
\end{tabular}


Vol. 5, No. 06; 2020

ISSN: $2456-8643$

\begin{tabular}{|llllll|} 
Yam & $4(6.6)$ & $41(67.2)$ & $16(26.2)$ & 0.80 & $13^{\text {th }}$ \\
Water melon & $1(1.6)$ & $12(19.7)$ & $48(78.7)$ & 0.23 & $18^{\text {th }}$ \\
Agricultural mechanization & & & & & \\
Tractor & $47(77.0)$ & $13(21.4)$ & $1(1.6)$ & 1.75 & $8^{\text {th }}$ \\
Sprayer & $53(86.9)$ & $6(9.8)$ & $2(3.3)$ & 1.84 & $6^{\text {th }}$ \\
Food safety techniques & $45(73.7)$ & $14(23.0)$ & $2(3.3)$ & 1.70 & $9^{\text {th }}$ \\
Soil testing & $4(6.6)$ & $31(50.8)$ & $26(42.6)$ & 0.64 & $15^{\text {th }}$ \\
\hline
\end{tabular}

Source: Field survey, 2019

( ) represent percentage

WMS represent Weighted mean score

\section{Communication channel employed by respondents in transferring Agricultural technologies to crop farmers}

Table 3 revealed the distribution of respondents according to communication channel employed in transferring Agricultural technologies to the respondents and it was revealed that most 67.2 percent) of the respondents used of Television as a communication channel in transferring Agricultural technologies to crop farmers, 54.1 percent used of Radio as a communication channel, very few (1.6 percent) used Newspaper as a communication channel, 61.3 percent made use of bulletin as a communication channel, majority (92.4 percent) of the respondents used face to face communication channel in transferring Agricultural technologies to crop farmers, few (21.3 percent) of the respondents used internet as a communication channel while majority of the respondents in the study area employed Demonstration as a communication medium channel in transferring Agricultural Technologies to crop farmers. This implies that Extension Agents in the study area employed different communication channel in transferring Agricultural Technologies to crop farmers but majority employed Face to face and Demonstration channel in transferring Agricultural technology to their crop farmers.

Table 3:Distribution of respondents according to communication channel employed in transferring Agricultural technologies to crop farmers

\begin{tabular}{|lrr|}
\hline Channels* & Frequency & Percentage (\%) \\
\hline Television & 41 & 67.2 \\
Radio & 33 & 54.1 \\
Newspaper & 1 & 1.6 \\
Bulletin & 38 & 61.3 \\
Face to face & 57 & 92.4 \\
Internet & 13 & 21.3 \\
\hline
\end{tabular}




\begin{tabular}{l|ll|} 
Demonstration & 59 & 96.7
\end{tabular}

\section{Source: Field survey, 2019}

* represent multiple responses

Pearson correlation analysis showing the relationship between selected socio economic characteristics and frequency of transfer of Agricultural technologies by Extension agents

Pearson's Product Moment Correlation analysis revealed that there is a positive and significant relationship between selected socio economic characteristics such as Age $(r=0.277, p=0.030)$, years spent in school $(r=0.713, p=0.000)$ and frequency of transfer of Agricultural technologies. This implies that increase in age of the respondent increases the level of transfer of Agricultural technologies to crop farmers. Also increase in the years spent in school of the respondent increases the level of transfer of Agricultural technologies to crop farmers.

Table 5: Pearson correlation analysis showing the relationship between the socio economic characteristics and the frequency of transfer of Agricultural technologies

\begin{tabular}{|llrl|}
\hline $\begin{array}{l}\text { Selected socio economic } \\
\text { characteristics }\end{array}$ & Correlation(r) & P-value & Remark \\
\hline Age & $0.277^{*}$ & 0.030 & Significant \\
Years spent in school & $0.713^{* *}$ & 0.000 & Significant \\
Household size & -0.249 & 0.053 & Not Significant \\
Annual income & 0.185 & 0.154 & Not Significant \\
\hline
\end{tabular}

Source: Field survey, 2019

*correlation is significant at the 0.05 level (2-tailed)

***orrelation is significant at the 0.01 level (2-tailed)

\section{CONCLUSION AND RECOMMENDATIONS}

The study concluded that key agricultural technologies transferred to crop farmers were hybrid maize and technology on plant population. Face to face and Demonstration were the two major communication channels employed by respondents in transferring Agricultural technologies to crop farmers. Based on the findings of this study, the following recommendations were made:

- More extension agents should be recruited into extension services to expand their coverage in the state.

- Demonstration tools should be made adequate and accessible to extension agents to assist in transfer of agricultural technologies to farmers.

\section{REFERENCES}

S.B Azumah, S.A. Donkoh and J.A Awuni (2018): F. Yildiz (Reviewing editor)The perceived effectiveness of agricultural technology transfer methods: Evidence from rice farmers in Northern Ghana, Cogent Food and Agriculture, 4:1 
Vol. 5, No. 06; 2020

ISSN: $2456-8643$

Accessed online at DOI: $\underline{10.1080 / 23311932.2018 .1503798}$

Davis, K. (2008). Extension in Sub-Saharan Africa: Overview and assessment of past and current models, and future prospects. Journal of International Agricultural and Extension Education, 15(3), 15-28

Mgendi G, Shiping M, and C. Xiang (2019): Sustainability 11, 6598, 1-20

Ohikere J. Z. and I. S. Arudi (2011): Nigerian Society for Experimental Biology Journal 11 (1) 29- $\quad 35$

Food and Agricultural Organization (2009): The Technology challenge: How to feed the world by 2050 , Rome, Italy. Available online at http://www.fao.org/fileadmin/templates/wsfs/docs/Issues_papers/HLEF2050_Technology.pdf

Accessed march, 2020 